\title{
Recent research on the limes in the Netherlands
}

\section{J. K. Haalebos and W. J. H. Willems}

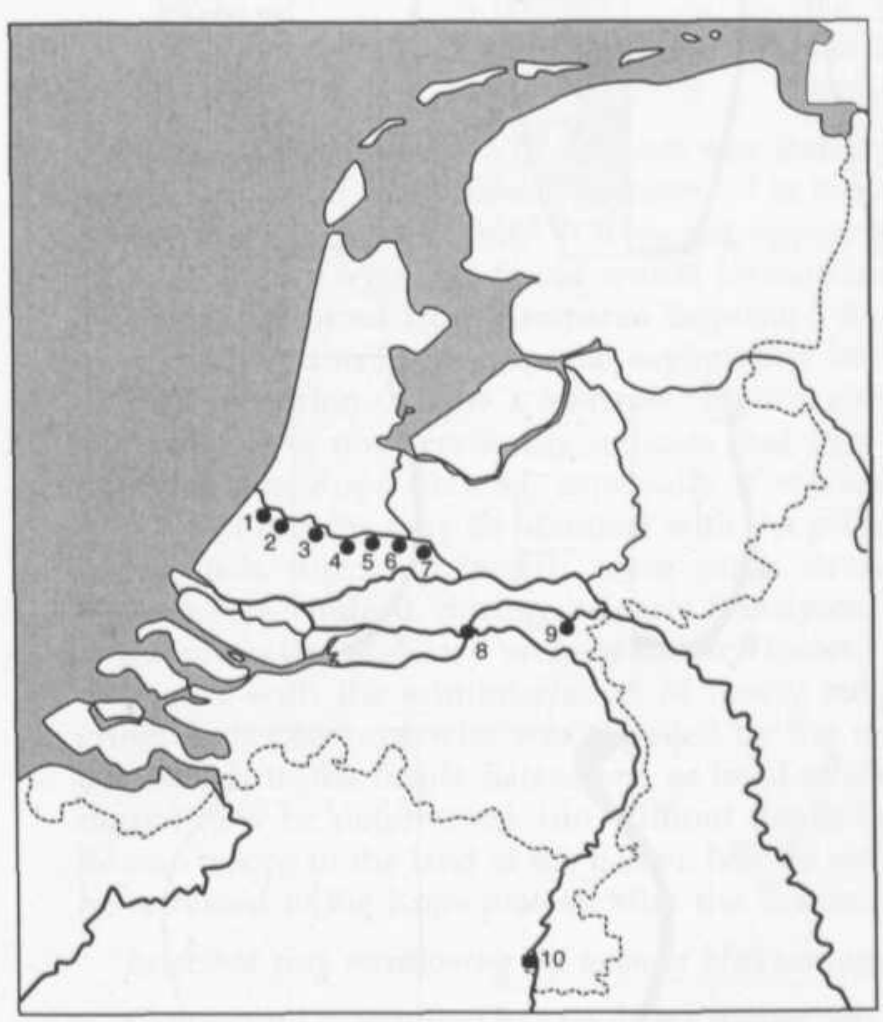

As a result of intense urban development and work on the modern infrastructure, the Dutch delta has become an area of equally intensive archaeological research. The delta coincides with the Roman frontier zone (fig. 1), and a rapid succession of new excavations and other work has shed new light on the Roman period. Although a general summary of the limes in Germania Inferior appeared in 1995 (Bechert and Willems), referring to the latest publications, a wealth of further information has since become available, and the present paper reports on some of the new investigations as well as referring to a few of the older finds. ${ }^{1}$

\section{Nijmegen}

The Augustan fort on the Hunerberg

The excavations in the large legionary fort on the Hunerberg at Nijmegen continued in $1996-97 .{ }^{2}$ For the first time a trench could be opened through the wall and ditches comprising the defences on the $\mathrm{W}$ side. It showed that the

Fig. 1. Map of the Netherlands and places mentioned in the construction made use of the natural text: 1 Valkenburg, 2 Leiden-Roomburg, 3 Zwammerdam, advantages offered by the topography. 4 Bodegraven, 5 Woerden, 6 Vleuten-De Meern, 7 Vechten, The wall was situatedat the top of a 8 Kessel-Lith, 9 Nijmegen, 10 Maastricht. Drawing ROB.

\section{slope and the ditches had been dug at} the foot.

The Augustan barrack-blocks, discovered in 1994, gave the prospect of finding further timber buildings in the adjoining area to the east. However, the excavation completed in the autumn of 1997 revealed only isolated foundation trenches, the purpose of which has yet to be explained. A relatively large number of refuse pits was found, including several deep ones, which have enlarged the still quite small series of coins from the Augustan fort. They support the earlier suggestion that the camp had already been abandoned before the first coins of the Lyon Altar type reached Nijmegen. In addition, the finest pottery assemblage hitherto known from this fort came to light (fig. 2): amongst other pieces it contained 3 Aco beakers with the names ACO and HILARVS, as well as a terra sigillata dish (Conspectus 8.3.1) with the stamp OLVS./ ALBIVS. Together with a second stamp of the Arretine potter Tarquitius (L.TAR on a plate of the type I b), this piece belongs to the earliest horizon of Roman finds on the Lower Rhine.

1 This paper is based in part on Haalebos and Willems (in press) which was prepared for the 17th Congress of Roman Frontier Studies held in Romania, 1997. It is chiefly intended to give an overview of discoveries from 1995 to 1998.

2 Haalebos 1995, 9-26. 

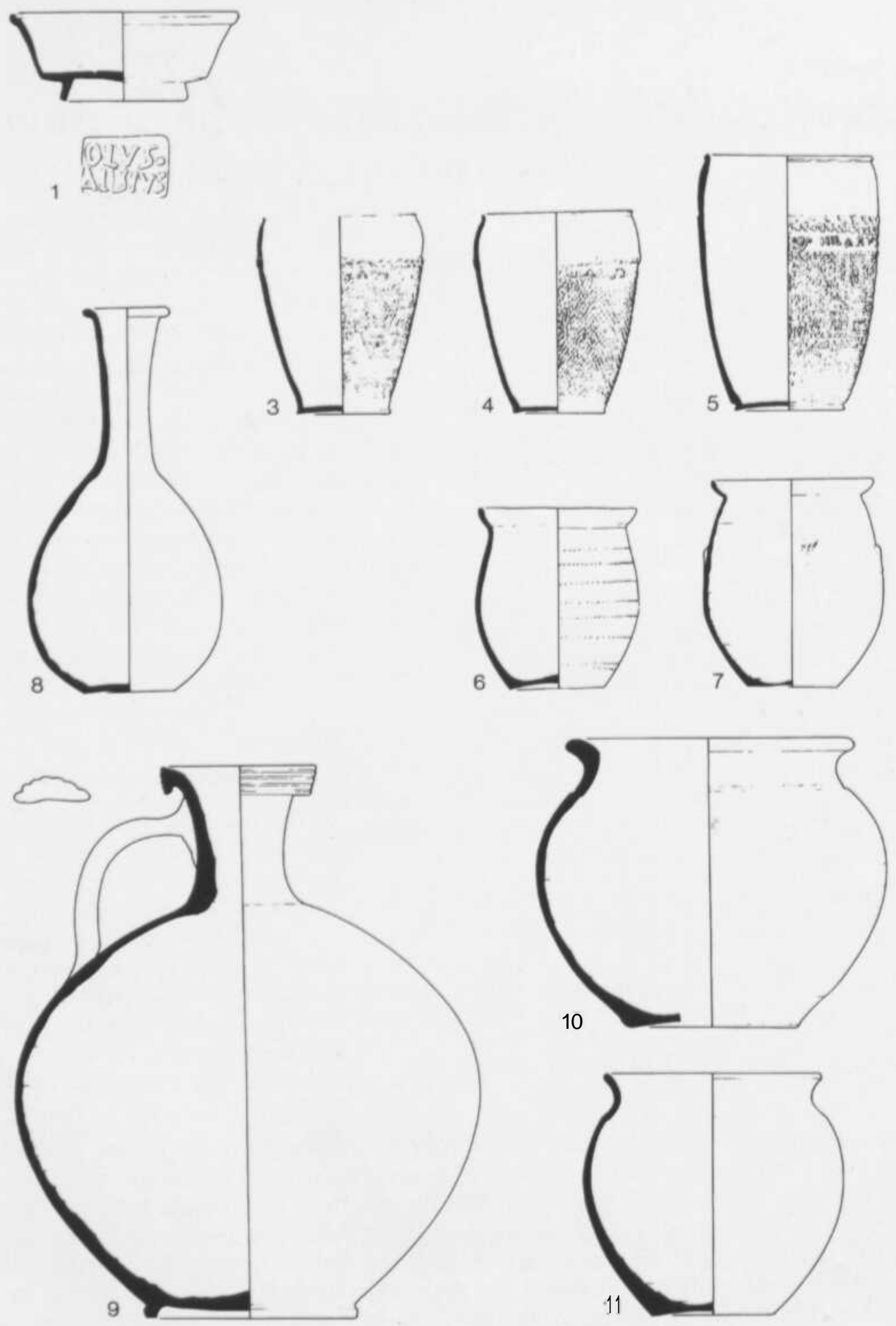

Fig. 2. Nijmegen, Hunerberg. Pottery from a refuse pit in the Augustan legionary camp. Scale 1:3. Drawing KUN.

\section{A property-tag of C. Aquillius Proculus, centurion of legio VIII Augusta}

Two small but very important inscriptions from Nijmegen that have already been published deserve brief discussion here. The first is a property-tag of a centurion of legio VIII Augusta (fig. 3) that was found on the Kops plateau. ${ }^{3}$ This ornamental bronze disk has a diameter of 6.3

3 Bechert and Willems 1995, 68, fig. 74; Van Enckevort and Zee 1996a, 67-68; 1996b, 22. 
$\mathrm{cm}$ and is plated with sheet silver. The letters of the inscription were cut into the metal and filled out with niello. The inscription reads:

$$
\begin{aligned}
& \text { C.AQVILLI } \\
& \text { PROCVLI } \\
& \text { כ LEG VIII } \\
& \text { AVG(ustae) }
\end{aligned}
$$

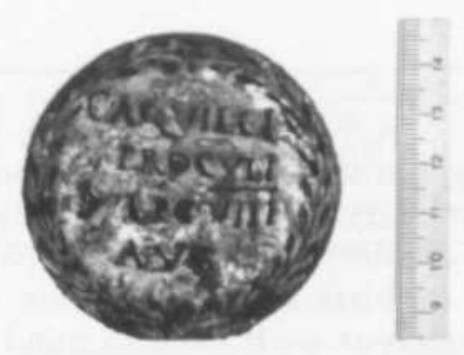

Fig. 3. Nijmegen, Kops Plateau. Silver plated bronze disk with the name of the primipilaris $C$. Aquillius Proculus. Scale 1:2. Photo ROB.

From Flavian times legio VIIlAugusta was stationed first at Mirebeau, then after 90 at Strasburg. ${ }^{4}$ The legion was probably transferred to these positions from the Balkans and Italy at the end of the Batavian Revolt. ${ }^{5}$ It does not appear ever to have been in Lower Germany. The stamped tiles of legio VIIlfound within Lower Germany are interpreted as building materials that were imported from Germania Superior ${ }^{6}$ Again in the case of the altar of a centurion of legio VIII found in Bonn, a special explanation can be suggested - that he had held the same rank of centurion in legio I Minervia, Bonn's garrison. Similarly, the new inscription from Nijmegen does not necessarily indicate that legio Vlll or even a vexillation from it had ever stood on the Kops plateau, especially if we are willing to believe that the centurion C. Aquillius Proculus may be identical with the primipilaris Aquilius mentioned by Tacitus (Hist. 4.15). Such former primipili were often detached from their own legion for special assignments. ${ }^{7}$ Indeed, during the early Principate, there was the possibility of being employed as the prefect of auxiliary units or cavalry forces. ${ }^{8}$ As praefecti civitatis such men could also be entrusted with the administration of newly subjugated tribes; this was the case with the primipilaris Olennius who was expelled by the rebellious Frisians. ${ }^{9}$ Why Aquillius had been transferred to the Insula Batavorum, as head of the administration or as commanding officer, cannot now be determined, but without doubt he was qualified to re-organise the defeated Roman troops in the land of the Batavi. Nor do we know where he had been stationed. Possibly he retreated to the Kops plateau after the Roman defeat.

\section{Inscribed ring mentioning the town of Noviomagus}

Our second inscription has no direct connection with the limes but, as the first documentation from inside the Netherlands of the ancient name of the town of Noviomagus, it requires a brief mention here. The inscription is on a silver ring (fig. 4) that was found in 1993 in the vicus (Ulpia) Noviomagus (later the Municipium Batavorum) during the excavation of two GalloRoman temples. ${ }^{10}$ The ring has a disc (diameter $2.7 \mathrm{~cm}$ ) and around the edge of the disc is a beaded decoration enclosing the inscription which shows that the jewellery was intended as a present to the goddess Salus. It reads:

.SAL(aluti).
SVTORIBVS
NOVIOM(agensibus).
J ESSERAVI
.D (ono).D(edit).D(edicavitque)

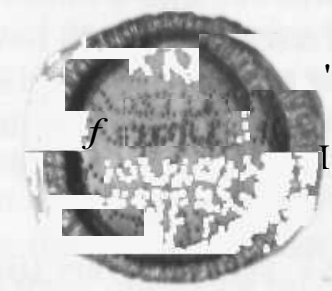

"To the goddess Salus, ${ }^{11}$ Rusticus for the cobblers of Noviomagus from the group (indicated with a reversed C) of Esseravus, has made a present and dedication [ofthis ri $)$

Fig. 4. Nijmegen-(Ulpia) Noviomagus. Silver ring with dedication to the goddess Salus. mentioning the sutores Noviomagenses. Scale 1:1. Photo KUN.

4 Goguey and Redde 1995, 379-80.

5 Oldenstein-Pferdehirt 1984, 400-2 and 405; see Tac., Hist. 4.68.

6 Baatz 1973, 220-21; Oldenstein-Pferdehirt 1984, 420 and 423, fig. 17.

7 Dobson 1978.

8 Ibid. 7.

9 Tac., Ann. 4.72: Olennius e primipilaribus regendis Frisiis impositus; compare Dobson, ibid. 176, 20.

10 Van Enckevort and Thijssen 1996, 76.

11 Before now this goddess was not known in the Netherlands. 
The translation of line 5 is especially difficult: it is probable that the reversed $C$ does not mean a military century, as is usually the case. If one attempts to see here a centuria from a collegium of cobblers from the town of Noviomagus, ${ }^{12}$ it leads to further difficulties since the high number of cobblers in this collegium would be unparalleled. Further, there is the unusual name Esseravus - it calls to mind the names of peoples similarly to Batavus, Chamavus, and Frisiavus, and also of names of rivers such as Saravus (the Saar) and Timavus (the Timavo near Aquileia). As Bogaers has observed, it is preferable to interpret the $\mathrm{C}$ as curia, referring to the native curiae, classified by C. B. Rüger in $1974 .{ }^{13}$ Such curiae ${ }^{14}$ were named, on the one hand, after places and groups and, on the other, after gods or persons (founders); they often have nonRoman-sounding names such as Curia Amratinna, Arduenna(e), Etratium, Ollodag(i), and Vardigiae. One could view them as religious and social groupings, connected with places that lacked town status. ${ }^{15}$ The names of some groups reveal ties to certain cults of matronae. Thus, we know of the Matrones Etrahenae and the Etrates, the Matronae Gesahenae and the Gesationes, and on that basis one could suppose that the Curia Amratinna was formed from the Amrates who had connections to the Matronae Amrahennae. If then we see a similar cult in the Curia Esseravi, this could suggest that the ring from Nijmegen indicates not a town but a non-urban civitas organisation and may date to the time when Noviomagus was still a simple vicus, without municipal status. The first dated reference to the Municipium Batavorum appears only in 227.

\section{The Roman limes}

Investigations on the limes have taken place primarily in the vicinity of some auxiliary forts. Excavations at Vechten and Valkenburg Z.H. were concentrated on the traces of the forts' $v i c i$, while those in Vleuten-De Meern and Noordwijk dealt with native settlements nearby, providing evidence for how the various inhabitants had intermingled in the frontier zone. Research at Valkenburg, Woerden and Vleuten-DeMeern has also provided important new information on the limes road.

\section{Leiden-Roomburg and the history of the cohors XV voluntariorum}

Excavations carried out in Leiden-Roomburg (Matilo) have provided evidence for the extension of the fort's vicus and new information for the strengthening of the banks along the fossa Corbulonis by revetments (see below), as well as a number of important finds including the visor-mask from a bronze parade-helmet (fig. 5) and a series of stamped tiles from cohors $X V$ voluntariorum. The possible military units that occupied Roomburg are the cohors I Lucensium piafidelis, the cohors $X V$ voluntariorum, and a numerus exploratorum Batavorum, all of which have long been known through inscriptions. Until now there was no indication for any of these auxiliary troops that they had horsemen at their disposal. The fragment of a helmet can be seen as evidence of the presence of cavalry at Roomburg if the common opinion that such helmets belonged to horsemen is correct. It would be preferable to see the cohors I Lucensium as the supposed cohors equitata.

The stamped tiles of cohors $X V$ voluntariorum (fig. 6 and Appendix below) present some problems. Stamps from this unit have been found outside the fort at Valkenburg and in several auxiliary forts and other sites east of Roomburg (Alphen-Zwammerdam, Bodegraven, Woerden, and Vleuten-De Meern). The largest number (20 fragments) came to light in Woerden, where all 5 of the known stamp-types have been found, including stamps with raised letters

12 As proposed by Van Enckevort and Thijssen 1995, 76. For the division of collegia in centuriae (and decuriae), see RE IV 1901, 418, s.v. collegium (Kornemann).

13 Rüger 1974, 251-60.

14 The word could have Celtic origins. The element -con- is known from several place- and tribal names, such as Coriovallum: see Rüger 1972, 256 and n.21.

15 Rüger 1974, 255. 

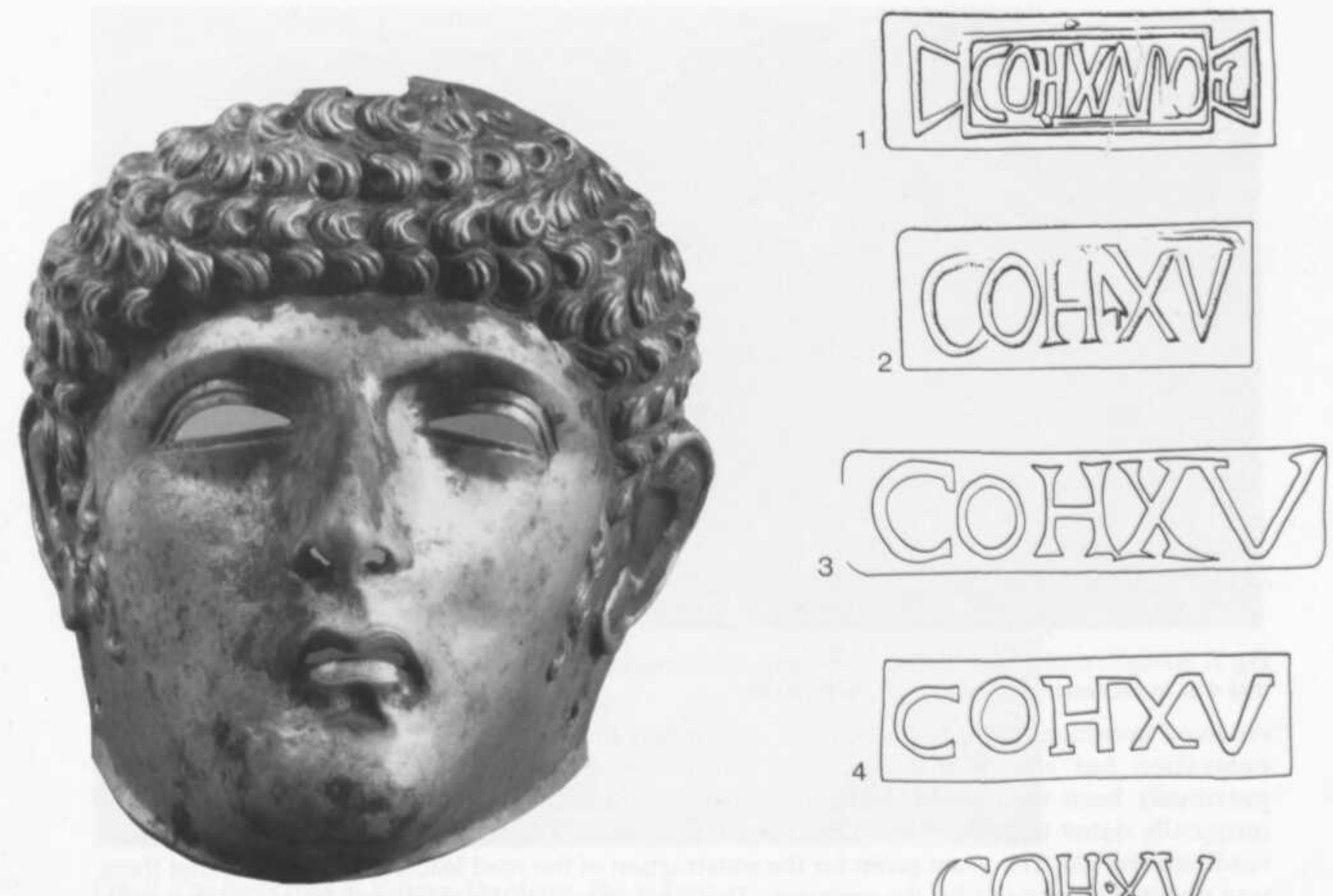

Fig. 5. Leiden-Roomburg. Visor mask of a bronze parade-helmet, found in the Fossa Corbulonis. Photo ROB.

Fig. 6. Woerden. Partially reconstructed tile-stamps of cohors XV voluntariorum. Drawing KUN.

(types 1-2) and those with incised letters (types 3-5); the first group appears to be the oldest and may be dated to the early Flavian period. A graffito on a one-handled jug proves the presence in Woerden of personnel from cohors $X V$ voluntariorum in about 100 . In the later $2 \mathrm{nd} \mathrm{c}$. this cohort was probably replaced here by the cohors III Breucorum, as is evident from an altar which the signifer L. Terentius Bassus set up to the gods Sol Elagabalus and Minerva. ${ }^{16}$ The stamps found at Woerden have also appeared in neighbouring forts: one at Vleuten-De Meern of type 2, one at Bodegraven (type 2), one at Alphen-Zwammerdam (type 3), one at Valkenburg (type 3), and about 10 at Leiden-Roomburg (types 3 and 4). This raises the question of whether the cohors $X V$ voluntariorum was split up among several forts. Was the unit transferred at some point from Woerden to Roomburg, or did it simply supply the neighbouring forts with tiles in its rôle as a building contingent? As long as it remains unclear whether tiles bearing the same stamp were actually fired in the same kiln, these questions probably cannot be answered.

\section{Valkenburg, and Caligula and Hadrian on the Lower Rhine}

Large-scale excavations at Valkenburg continued into 1997 and have revealed the complicated history of settlement along the bank of the river south of the fort. The various elements -military structures, buildings of the vicus, native farmsteads, and graves - were all dependent on the main limes road. The wooden pilings of all phases of its substructure have been found. The road had at one time been shifted further inland because of flooding. From dendrochronological analysis the two phases of the road seemed to be dated to the years $39-40$ and 124 , but

16 Bogaers 1994. 


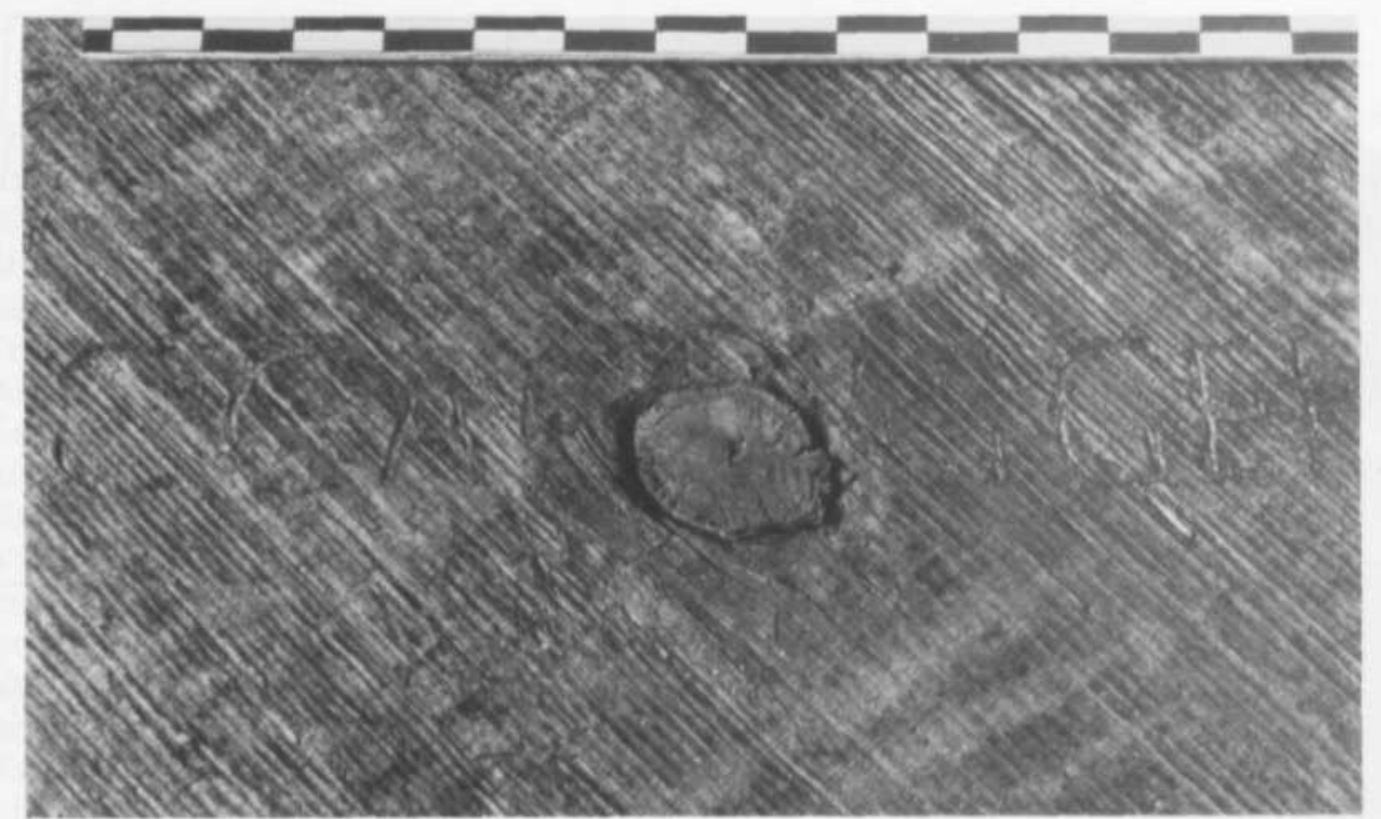

Fig 7. Stamp C CAE[S A]VG GER. The stamp was burned into the wood across the vent of a wine barrel that was in secondary use as a well. Photo ROB.

renewed investigation of the wood has shown that this was incorrect. Further analysis of the excavation has shown that the road had three phases, of which the earliest had not previously been recognized. ${ }^{17}$ The first phase is not precisely datable, but the second phase (originally dated to $39-40)^{18}$ must have been built under Trajan in 99-100; the date of the third road remains 124. The years given for the construction of the road lead one to suppose that there was direct involvement by the emperor. The third phase of the road may be associated with Hadrian who visited Gaul and Germany in 121-123 and who ordered the construction of the palisade in Germania Superior. ${ }^{19}$ We may suppose that on his visit to the Lower Rhine the emperor ordered its repair, and indeed the discoveries at Woerden and Vleuten-De Meern indicate that an extensive building programme was initiated by Hadrian. ${ }^{20}$

The earlier phase had seemed to belong to the time of Caligula and thereby settle the dispute over the date of the beginning of the fort at Valkenburg; ${ }^{21}$ the foundation of this auxiliary fort had been thought by Van Giffen and Glasbergen to be connected with the Claudian invasion of Britain, but subsequently on the basis of historical and epigraphic considerations and from analysis of the coins an earlier date was proposed. ${ }^{22}$ The latter hypothesis seemed to be supported by a brandmark naming Caligula found on a barrel from the oldest fort. ${ }^{23}$ The second line of the inscription was not previously read.

\section{C.CAE.AVG.GER \\ IVLIOR BALON}

A similar brandmark has now been found at Vechten on a wine barre ${ }^{24}$ which had been insert-

17 This and other information on the limes road at Valkenburg and Vleuten-De Meern is discussed in detail by Hessing 1999.

18 Hallewas and Van Dierendonck 1993, 17-21. For road construction under Trajan see the section on Elst below.

19 SHA, Had. 10 and 12.

$20 \quad$ See also Hessing 1999.

21 The new date from dendrochronology of 99-100 illustrates that the samples were not taken from the oldest road. The new date implies that the road can no longer serve as supplementary evidence for the date of the oldest fort at Valkenburg.

22 Haalebos 1977, 283-84; De Weerd 1977, 282.

23 Bogaers 1978, 10-11; see also now Wynia 1999.

24 Campaign of 1995, find no. 5-8-1715. See Hessing 1997, 53-54 and Wynia 1999. 


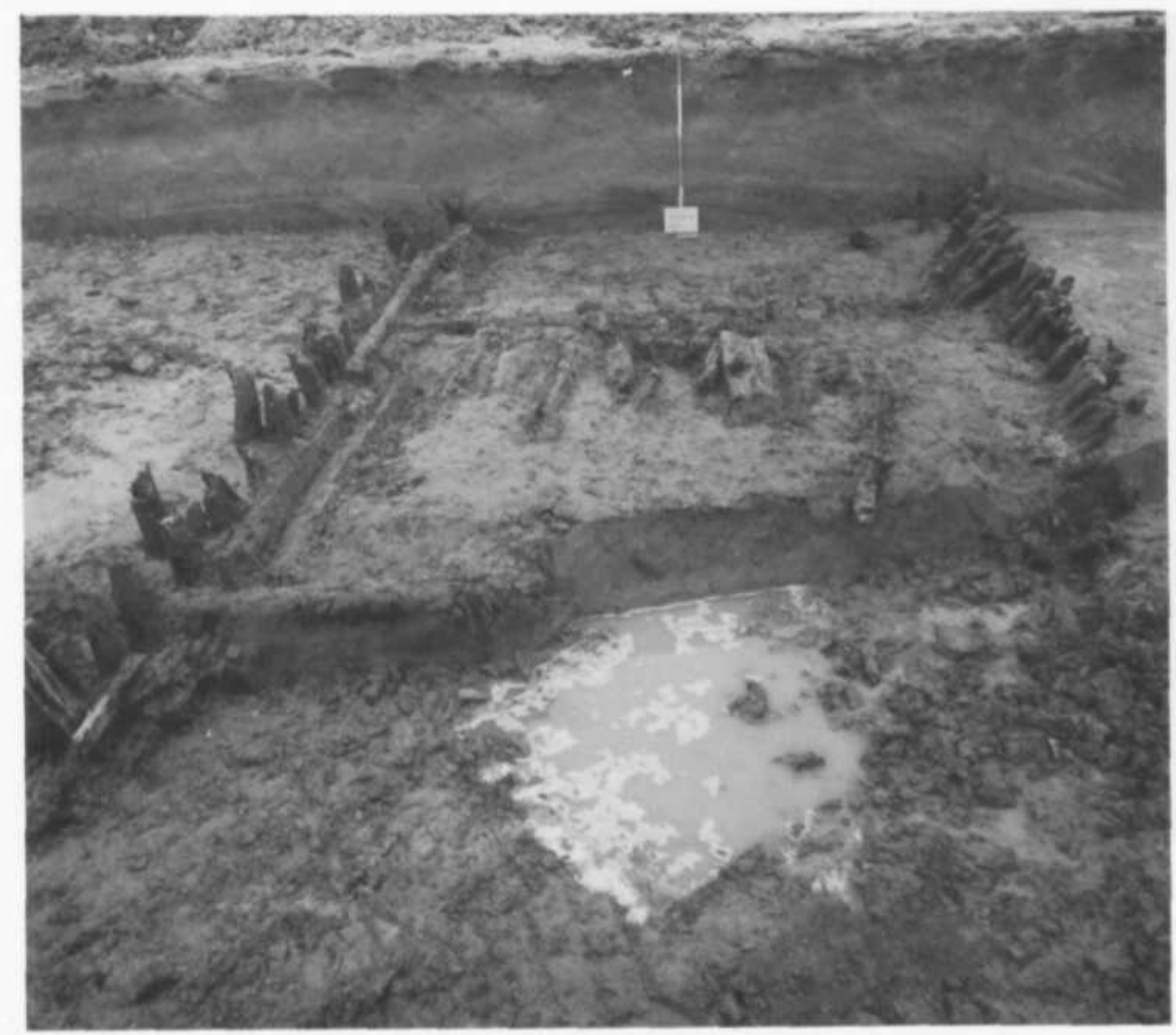

Fig. 8. The limes road at Vleuten-De Meern. Photo ROB.

ed into the ground to be used as a well (fig. 7). This new find proves that the example from Valkenburg is not isolated and could relate to military activities and the supplying of the troops on the Lower Rhine in which perhaps Caligula himself took part. Here we may recall the antiquarian tradition in the Netherlands which sees Caligula's expedition against Britain as ending not on the channel coast but at Katwijk on the North Sea. This view may receive some support from two passages in Tacitus. One says of Brinno of the Canninefates, a leader in the Batavian revolt, that his father committed many hostile acts and, without getting punished for it, held the ridiculous campaign of Gaius (Caligula) to be of little worth. ${ }^{25}$ The second passage connects the British adventure with the equally unsuccessful massive attempts at subjugation directed against Germania (ingentes adversus Germaniam conatus). ${ }^{26}$ From these one could suppose that a large-scale military operation was carried out by Caligula in the territory of the Canninefates on the Lower Rhine. In any event, both texts gain renewed interest in the light of the recent finds.

The limes road at Vleuten-De Meern

The dendrochronological evidence and re-interpretation of the limes road at Valkenburg is paralleled by new discoveries near the fort of Vleuten-De Meern. Excavations in 1997-98, necessitated by a large urban development scheme at Veldhuizen, uncovered two native Roman settlements and segment of the limes road $1400 \mathrm{~m}$ long. ${ }^{27}$ As at Valkenburg, the road had three phases, the first undatable, the second built with wood including oaks that had been felled in the winter of 99-100, and the third a massive dyke-like construction (fig. 8 here; see also Hallewas 1993, figs. 4-6), built of oaks dating to the winter of 124-125. The same dates have been

25 Hist. 4.14, 15: pater eius multa hostilia ausus Gaianarum expeditionum ludibrium impune spreverat.

26 Agric. 13.4: agitasse Gaium Caesarem de intranda Britannia satis constat, ni velox ingenio mobili paenitentiae, et ingentes adversus Germaniam conatus frustra fuissent.

27 A preliminary analysis was published by Graafstal 1998; see also Hessing 1999. 


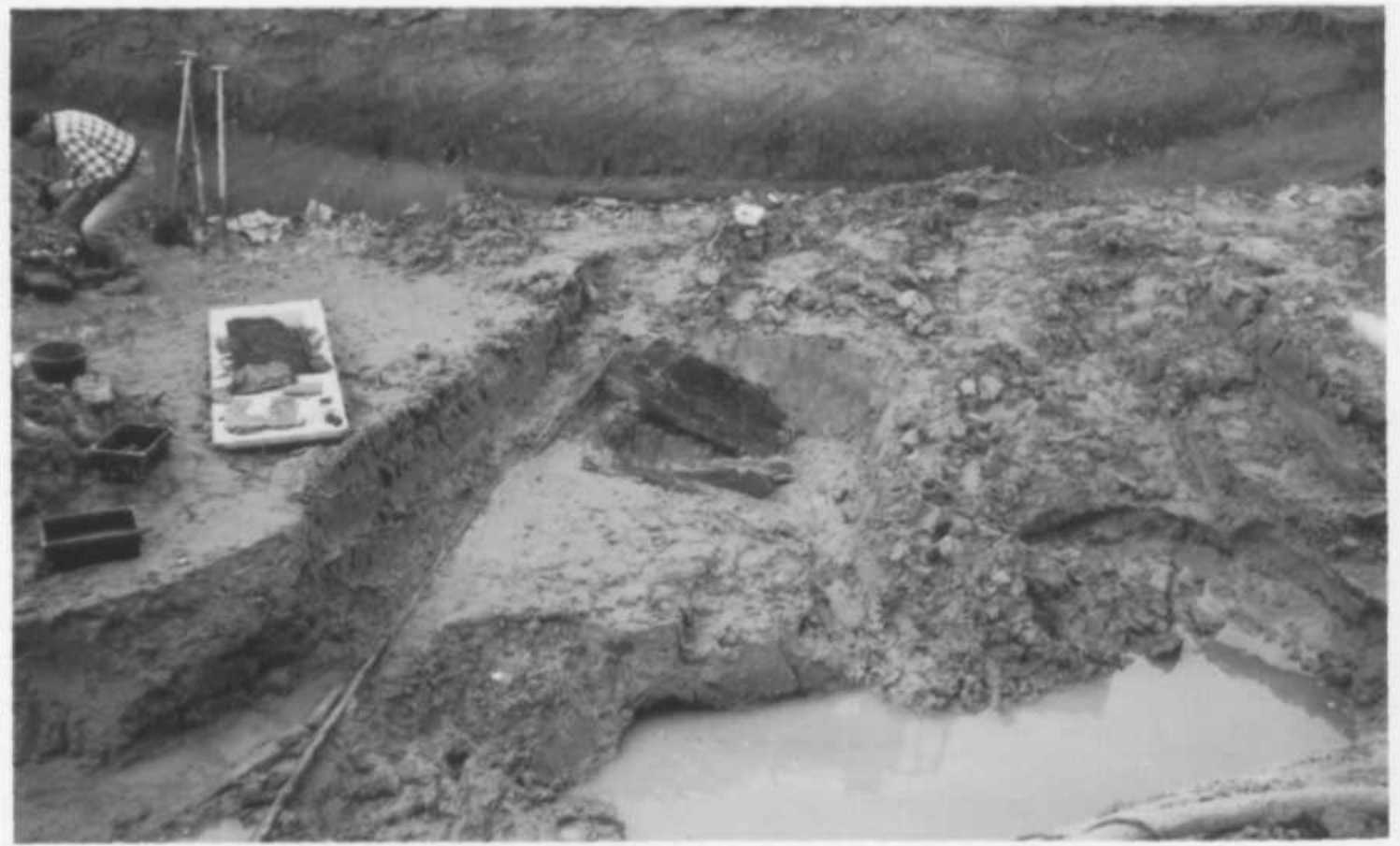

Fig. 9. The Roman river barge from Vleuten during its discovery in autumn 1997. The vessel has been covered up again and awaits full excavation in the near future.

established for rows of wooden posts found along the Rhine near the fort at Woerden. ${ }^{28}$ The wooden revetments built to reinforce the bank of the Fossa Corbulonis at Leiden-Roomburg also date to 124-125, with an earlier phase constructed from oaks felled in 86-87 (this is noted by Hessing 1999). Thus there is evidence for work on infrastructure particularly under Trajan and Hadrian. Epigraphical evidence from Elst (see below) further argues for Trajanic work. Even more extensive work seems to have been carried out by Hadrian. It now seems likely that this included a dyke carrying the limes road on the $S$ bank of the Rhine that may have been about $40 \mathrm{~km}$ in length, from Valkenburg to Vleuten; the actual works may have been even more extensive but we do not have evidence for a continuation further to the east.

The silted-up channel of the Rhine at Vleuten yielded two boats, one a partially-preserved dugout canoe of probable Roman date, the other what seems to be a completely preserved river barge, $26 \mathrm{~m}$ in length, of the Zwammerdam type. In 1997 part of the stern was excavated (fig. 9) $;{ }^{29}$ it yielded among other items a toolbox and a caulking iron. The finds show that the boat was not sunk deliberately, like most other vessels found thus far, but may have met with some catastrophe around the end of the 2nd c. Excavation of this barge should provide the most complete evidence for this type of vessel.

\section{Elst: Trajan and the auxiliary troops of Germania Inferior ${ }^{30}$}

In 1988 the fragment of a military diploma (fig. 10) was found near Elst. This diploma is exceptionally important because it mentions numerous auxiliary units and names Trajan as the commander in chief of the army of Lower Germany. The text with supplements reads:

28 In the autumn of 1998 a row of oak posts was found here that may be part of the foundation of a road. Dendrochronological examination has shown it consists of two groups of posts: one from 99-100, the other dating to the early 120s. The excavation is not yet published but see Haalebos 1996, 475 and Taf. 75.1 .

29 Graafstal 1998, 146-50.

30 The find was studied by $f$. E. Bogaers whose untimely death in 1996 prevented publication of the results. This section is a summary of a full report about to appear in the Saalburg-Jahrbuch (1999), where full supporting notes will be found. 
[Imp(erator) Caesar, divi Nervae f(ilius), Nerva Traianus Aug(ustus) Germ(anicus), pont(ifex) maxim(us), trib(unicia) potest(ate), co(n)s(ul) II

equitibus et peditibus, qui militant in alis VI(?) et cohortibus XXV(?), quae appellantur

[(1) Sulpicia et (2) In]dian(a) et (3) I Noricor(um) [et (4) I Batavor(um) et (5) - et (6) Af]ror(um) et

(1) I Hispanor(um) et (2) I Pannonior(um) [et (3) I — et (4) I Thrac(um) et (5) I Fl] avia Hispanor(um) et (6) I Pannonior(um) et Delmatar(um) [c(ivium) R(omanorum) et (7) I Vindel]icor(um) c(ivium) R(omanorum) mil(liaria) et (8) I Raetor(um) c(ivium) R(omanorum) et (9) I Classica et (10) I Lu[censium et (11) I] Latobicor(um) et Varcianor(um) et (12) I et (13) II c(ivium) R(omanorum) et (14) II et (15) II Hispa[no]r(um) et (16) II Astur(um) et (17) II Varcianor(um) et (18) II Brittonum mi[l(liaria) et (19) II Thr]ac(um) et (20) III Lusitanor(um) et (21) III Breucor(um) et (22) II1I Thrac(um) [et (23) VI] Breucor(um) et (24) VI Raetor(um) et (25) VIBrittonum

et sunt in Germ[ani]a inferiore sub Imp(eratore) Traiano Aug(usto), qui quin[a et v]icena plurave stipendia meruerun[t, $\mathrm{i}]$ tem dimiss[is ho]nesta missione emeritis stipendiis, $\mathrm{e}[\mathrm{t}]$ classicis qu[i milit]ant sub eodem, praef(ecto) L(ucio) Calpurnio Sab[ino, senis et vic]enis stipendiis emeritis, quorum no[mina subscript]a sunt, ipsis, liberis posterisque e[orum civitatem d]edit et conubium cum uxoribu[s quas tunc habuiss]ent, cum est civitas iis data, aut, $\mathrm{s}$ [iqui caelibes essent, cu]m iis, quas postea duxissent, d[umtaxat singuli sing]ulas.

a(nte) d(iem) X K(alendas) Mart(ias) Imp(eratore) Caes(are) [Traiano Aug(usto) G]erm(anico) II, Sex(to) Iulio Frontino II co(n)[s(ulibus).]

[Alae I Bat]avorum, cui prae(e)st [---] T(iti) f(ilius) Vol(tinia tribu) Rufus, [dimis]so honesta missione ex gregale [---] Gaveri f(ilio), Batav(o) [et - Pere]grini filiae, uxori eius, Bat(avae) [et ---]e fil(iae) eius [et --]ae fil(iae) [eius.]

[Descriptum et] recognitum ex t[abula aenea, quae fixa est Ro]mae in mur[o post templum divi Aug(usti) ad Minerva]m.

\section{Translation}

Imperator Caesar Nerva Traianus, son of the deified Nerva, Augustus, conquerer of the Germans, high-priest, vested with the authority of a tribune of the people and consul for the second time, has granted

to the cavalrymen and to the infantrymen, who are serving in the (6?) mounted and $25(?)$ foot regiments, which are called

Ithere follow the names of at least 6 cavalry (alae) and 25 infantry regiments (cohortes)]

and are in Lower Germany under the imperator Traianus Augustus, after 25 or more years service, as well as those honourably discharged at the end of active service and the soldiers of the fleet, who under their prefect Lucius Calpurnius Sabinus likewise belonging to Trajan's command, having served for 26 years or more, the rights of citizenship; he has conferred it upon themselves, their children and their descendants, and furthermore granted them the (legally recognized) marriage with the women with whom they are living at the time of the presentation of citizenship, or with those that they marry later, if there should be some that are living alone at the moment, but being restricted to one wife respectively. The names of the beneficiaries will be entered below.

On the 20th of February as the imperator Traianus Augustus Germanicus, and Sextus Iulius Frontinus were consuls for the second time.

To the honourably discharged, former horseman of the first regiment of Batavians under the command of [---] Rufus, Titus' son, from the tribe Voltinia, [---], Gaverus' son, a Batavian and to [---], [Pere]grinus' daughter, his wife, a Batavian, and to [---]a, his daughter, and to [--], his daughter.

Controlled and verified with the tablet of bronze, which is mounted on the wall behind the Temple for the deified Augustus in Rome near the Temple of Minerva.

This diploma was given to a discharged Batavian horseman (gregalis) from an ala Batavorum which belonged to the army of Lower Germany. This ala could possibly be the same unit as the ala Batavorum milliaria pia fidelis which is later recorded in diplomas from Pannonia and Dacia (after 113). Both the man's nationality and the name of the unit are surprising as one would hardly have expected to find a Batavian unit in Lower Germany after the Batavian revolt, especially one with Batavians in its ranks. It could be the case, however, that in the 
TABLE 1: SUMMARY OF THE AUXILIARY UNITS MENTIONED IN THE MOST IMPORTANT DIPLOMAS FROM LOWER GERMANY.

$\begin{array}{lccccc}\text { Wiesbaden } & \text { Kamensko } & \text { Elst } & \text { Bulgaria } & \text { Xanten } \\ 15 \text { April } 78 & \text { 1 February 80 } & \text { 20 February 98 } & \text { 20 August 127 } & \text { ?February/March } 158\end{array}$

ALAE

6

$6 ?$

5

4

Siliana

IFl. Sing.

I Moesica

6. Afrorum

3. I Noricorum

1. [Sulpicia]

4. I Batavorum

$\mathrm{X}$

$84 \mathrm{~Pa}$

pf 90Gs

$\mathrm{X}$

$\mathrm{X}$

pf

2. Indiana

Thrac. <et Gall.>

$<$ Gall. et> Thrac.

Classiana

\begin{tabular}{|c|c|c|}
\hline $\mathrm{pf}$ & & $<120 \mathrm{Gs}$ \\
\hline & $\mathrm{x}$ & \\
\hline & $\mathrm{X}$ & \\
\hline & {$[\mathrm{x}]$} & \\
\hline pf? & $\mathrm{x}$ & $112 \mathrm{PS}$ \\
\hline & $\mathrm{x}$ & \\
\hline
\end{tabular}

$\mathrm{X}$
$\mathrm{X}$
$\mathrm{x}$

$124 \mathrm{Br} \quad \mathrm{X}$

$129 \mathrm{GS}$

$122 \mathrm{Br} \quad \mathrm{X}$

$\mathrm{Gi}$

Not mentioned in the diploma: ala Augusta Vocontiorum

COHORTES

VIThracum

VIAsturum

III Dalmatarum

4. I Thracum

16. II Asturum

19. II Thracum

5. IFl. Hispanorum $\times$

13. II civ. Romanor.

9. I Classica

22. IIII Thracum

11. I Lat. et Varcian.

24. VI Raetorum

1. I Hispanorum

7. I Vindelicorum

2. I Pannoniorum

12. I civium Romanorum

14. II Hispanorum eq.

18. II Brittonum mil.

20. III Lusitanorum

8. I Raetorum

10. I Lucensium

15. II Hispanorum ped.

25. VI Brittonum

17. II Varcianorum

21. III Breucorum

23. VI Breucorum

6. I Pann. et Delm.
11

$$
\mathrm{X}
$$

[x]

[x]

[x]

$\mathrm{X}$

[x]

$\mathrm{x}$

$\mathrm{x}$

$\mathrm{X}$

$\mathrm{X}$

$\mathrm{x}$

[x]

$84 \mathrm{~Pa}$

$$
\text { pf 90Gs }
$$

Pf

pfd

[x] 100Ms' $110 \mathrm{Pi}$

Pf

Pf

pfd

pfd

Pf

$\mathrm{X}$
$[\mathrm{x}]$ X

$135 \mathrm{Pi}$

$\mathrm{X}$

X

$\mathrm{x}$
$\mathrm{x}$

$x$

x

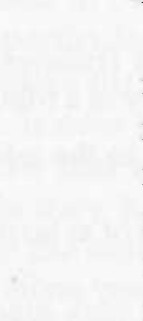

$\begin{array}{lll} & & 163 \mathrm{No} \\ \mathrm{X} & \mathrm{X} & \mathrm{Gl} \\ \mathrm{X} & \mathrm{G}, & \\ \mathrm{X} & \mathrm{X} & \mathrm{Gi} \\ \mathrm{X} & \mathrm{X} & \mathrm{Gi} \\ \mathrm{X} & \mathrm{X} & \mathrm{Gi} \\ \mathrm{X} & & 166 \mathrm{Br}\end{array}$

$103 \mathrm{Ms}$

$100 \mathrm{Ms}$

$103 \mathrm{Ms}$

116GS

$85 \mathrm{P} ?$

pf?

Pf

$\mathrm{x}$

99Ms? 116Gs

$\begin{array}{lll}\text { Pf } & X & 100 M s \\ \text { Pf } & X & 110 \mathrm{Pi}\end{array}$

$\begin{array}{lll}\text { Pf } & X & 100 M s \\ \text { Pf } & X & 110 \mathrm{Pi}\end{array}$

Pf $\quad X$

Pf $\quad x$

Pf $\quad X$

pf $\quad x$

pf?

Not mentioned in the diplomas, but belonging to the army of Lower Germany under the Flavians: cohors VI Ingenuorum mill., cohors $X V$ voluntariorum c.R. $p, f$.

Key: $\mathrm{Pa}=$ Pannonia $; \mathrm{Pi}=$ Pannonia Inferior Ps $=$ Pannonia Superior $; \mathrm{Br}=$ Britannia $; \mathrm{Gi}=$ Germania Inferior; $\mathrm{Gs}=$ Germania Superior; Ms $=$ Moesia. 


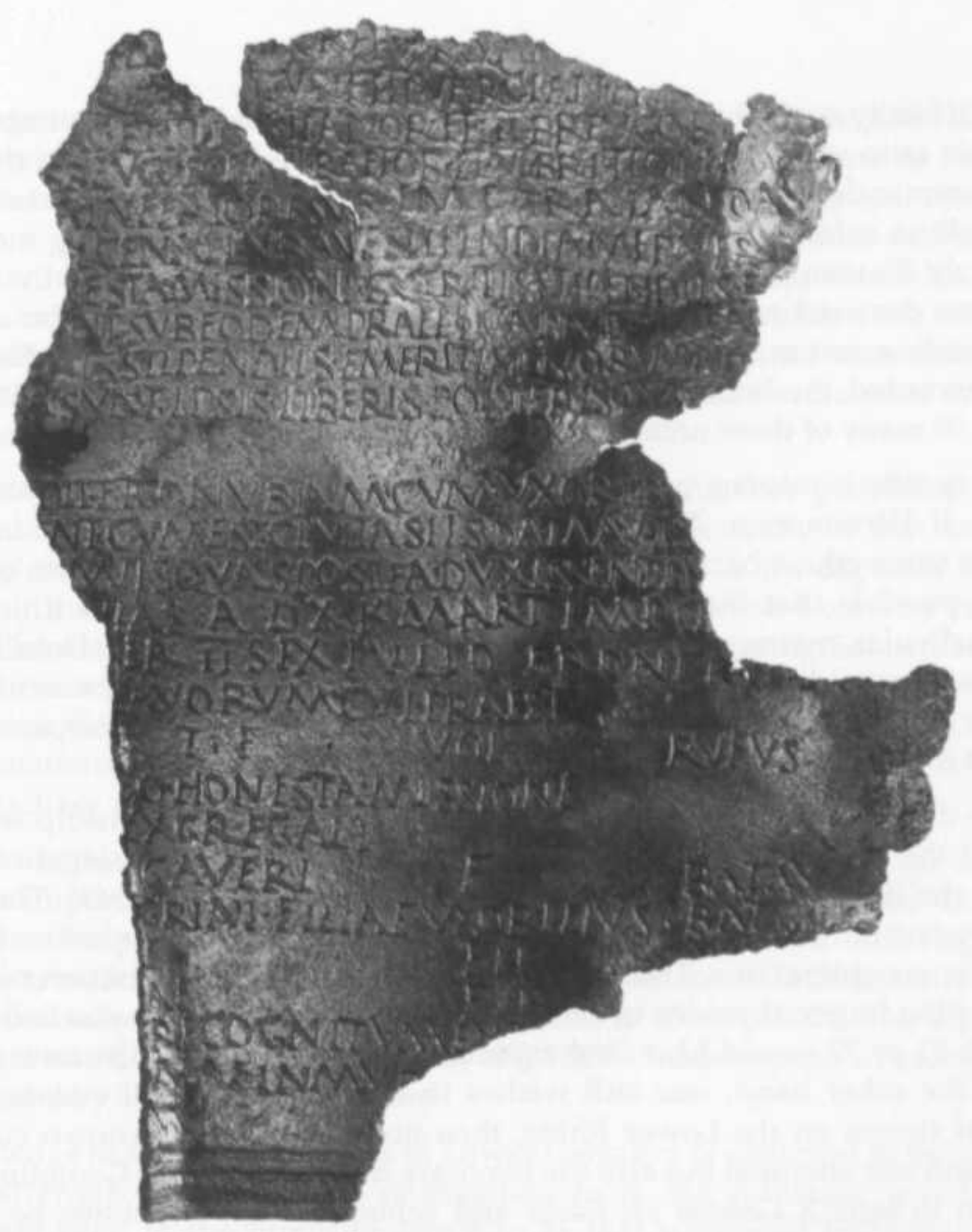

Fig. 10. Eist-Lijnden. Diploma (extrinsecus, Tabella I) from a former horseman from the ala Batavorum, dated to 98. Photo ROB.

Flavian period the cohors I Batavorum milliaria civium Romanorum pia fidelis, which is also mentioned in a diploma from Pannonia, was stationed in Lower Germany as well.

If this cavalry regiment can be identified with the ala Batavorum milliaria pia fidelis, known at a later date from Pannonia and Dacia, then it must have been in Germania Inferior before 89 , like cohors 1 Batavorum. It remains uncertain if both units were previously employed in another province; it is however possible that under the Flavians they stayed in the vicinity of their Batavian homeland.

One should bear in mind that the Batavian revolt had not been a unified national uprising of the people. There had clearly been two factions involved: a pro-Roman attitude, and the rewarding of such through the granting of Roman citizenship, appears to be evident occasionally in the naming of Batavians; so the prefect of the Batavian regiment in Vindolanda had the cognomen of the legate Q. Petillius Cerialis who had suppressed the revolt, while a former decurion from the ala Frontoniana (Tungrorum), C. Petillius Vindex Batavus, had the gentilicium. ${ }^{31}$ Our cavalryman from Elst must have entered the army shortly after the Batavian revolt. When considering the 25 or more years of service mentioned in the diploma, this could even have happened immediately after the conflict. Where he had been stationed remains unknown, but he returned with his family to the Insula Batavorum (today known as Betuwe) with Elst at its centre (fig. 1). 
The main difficulty with this diploma lies in the unexpectedly large number of regiments and the question as to whether this has something to do with the presence of the emperor who is named as commander in chief of the army of Lower Germany. With 6 alae and at least 25 cohortes, as well as soldiers of the fleet, the diploma names significantly more than the 17 units of the early Flavian diplomata, or the 20 units of the diploma recently found in Glava (Bulgaria). ${ }^{32}$ One does not necessarily have to see this as an indication of the concentration of troops for a specific event in 98. Many of the units listed in the diploma from Elst can be shown to have been awarded the honorary title of pia fidelis after the uprising in 88 . One can thus assume that by 98 many of these units had already been in Lower Germany for some 10 years.

This honorary title is missing only with a small group, consisting of cohortes I Pannoniorum et Dalmatarum, II Varcianorum, III Breucorum and IV Breucorum. The units mentioned have more or less the same ethnic background. All four cohortes come from the area of Pannonia and Dalmatia. It is possible that these troops were transferred to the Lower Rhine by Nerva or Trajan for a particular reason, perhaps to bolster the army against pro-Domitian sentiments current amongst the soldiers of Lower Germany. This interpretation of events is impossible, however, if the cohors II Varcianorum was already in Germania under Vespasian, as has been supposed, ${ }^{33}$ but one may doubt that this was the case.

On the same day as the diploma from Elst - 20 February, 98 - citizenship was also granted to soldiers from the armies of Pannonia and Britannia who fulfilled the legal requirements, as we know from the diplomas from Felsönána and Flémalle (CIL XVI 42-43). The issuing of the Elst diploma appears not so much to be connected with incidents peculiar to Lower Germany but to relate to wider considerations. Thus, a correlation with the re-organisation of the army after the conflict over the Imperial power in 69 and 70 is likely, for soldiers who had been recruited into the army in 71 or 72 would have first expected their discharge by the time of Nerva at the earliest. If, on the other hand, one still wishes to introduce regional events to explain the concentration of troops on the Lower Rhine, then not only the well-known coins portraying Germania demand our attention but also the honorary inscription for Q. Geminius Sabinus ${ }^{34} \mathrm{He}$ was a centurion in legio $X$ Gemina pia fidelis and achieved high positions; he probably took part in Trajan's German campaigns as princeps peregrinorum and thereby earned himself military decorations.

We may also note that during the early years of Trajan's reign improvements to the infrastructure were evidently being carried out. The oldest known milestones from Germania Inferior date from this period. The stone from Beek near Nijmegen is dated to the years 98-102 by what survives of the emperor's titles, which can be completed on the basis of CIL XVII 574 found at Koblenz in exactly the same manner as the milestone fragment from Xanten so that the date falls within Trajan's second consulate of 98-99. One can probably connect this milestone with improvements of the limes road, as is confirmed by the new dendrochronological data from the wood of this road near Valkenburg, Woerden and Vleuten-De Meern, discussed above.

We are poorly informed about the military operations. Scholars usually combine two commentaries to elucidate the situation. Pliny, Ep. 2.7.2, reports that the Senate donated a triumphal statue auctore principe for T. Vestricius Spurinna because of his success against the Bructeri. The description of the victory in Pliny's letter recalls the report in Tacitus, Germ. 33, on the expulsion of the Bructeri from their lands by their neighbours. Both authors praise this victory as an event of the happiest kind in that the Roman military was present only as spectators and could observe how the Germans slaughtered each other. The dating of the defeat of the Bructeri is uncertain because the name of the emperor is missing in Pliny's account; thus, the exact date of Spurinna's governorship is unknown.

32 Eck and Paunov 1997.

33 Alföldy 1968, 74-75.

34 Dobson 1978, 222, no. 103. 
All this brings little clarity to the rôle of Trajan on the Lower Rhine. Literary sources indicate that he stayed in Cologne during the first months of 98. At that time he had already been replaced as governor of Germania Superior by L. Iulius Ursus Servianus. It remains unclear if there was even a governor present in Germania Inferior. Was Spurinna still in office, or had Trajan taken over his function? The diploma from Elst places the army under his command, and as imperator, in any event, as a result of his imperium maius he wielded the absolute authority. But his status in the diploma appears thereby to have been somewhat unique, really only comparable to that of the imperial princes Drusus, Tiberius and Germanicus at the time of the conquests.

It remains doubtful that troops had to be ordered from other provinces for what were apparently not large-scale operations. The army of Lower Germany at that time numbered 4 legions. Most of the more than 30 auxiliary units mentioned in the diploma seem already to have spent 10 or more years in the province. Only in the case of 4 cohortes from the area of Pannonia and Dalmatia is their presence in Germania Inferior during Saturninus' rebellion not attested. It is therefore possible that the diploma from Elst comprises a fairly complete list of the army of Lower Germany to which only a few units need to be added. It is conspicuous that cohors $X V$ voluntariorum is missing, yet this unit had a different composition from that of most of the other auxiliary regiments.

If one could use the Elst diploma to estimate the size of the army of Lower Germany in 98 it would provide important indications of changes in the size of that army in Flavian times. Alföldy (1968) attempted to show that after the Batavian revolt full-strength auxiliary regiments were transferred to the Lower Rhine (a total of about 15,500 men), and that in the following decades this number was gradually reduced to about 13,000 . The diploma from Elst now gives a total number of 3,000 cavalrymen and 15,500 infantrymen, whereby this last figure should be increased by 500-1000 men or more.

If our knowledge of the auxiliary units in Lower Germany is sufficient to point to the changes in their total strength, one gains the impression, from the summary given here, that the development has been in the opposite direction to that suggested by Alföldy. Until 89 the number of auxiliaries appears to have remained fairly constant at about 14,000 men. Perhaps 4 Pannonia or Dalmatian regiments joined them during the next decade (because the honorary title pia fidelis is lacking, these may be seen as newcomers to Germania Inferior). However, greater changes can be seen in the years after Trajan's stay. It seems that the emperor had been mainly occupied with organizing the province in such a way as to leave it in stable condition and draw off troops for the anticipated wars on the Danube. In its list of auxiliaries the Bulgarian diploma of 127 has at least 10 units fewer. The ala Batavorum and 8 cohortes could have been transferred to the Danube region in about 100. Their transfer and the withdrawal of legio $X$ from Nijmegen show to what extent the military situation had changed during the first years of the 2 nd c. One can assume that this had been planned in 98.

The Late Empire

\section{Nijmegen}

The most important excavations in late Roman fortresses have been conducted at Nijmegen and Maastricht. At Nijmegen a new building for the Museum Het Valkhof was responsible for an excavation next to the Valkhof ${ }^{35}$ which has shown, amongst other things, that the two ditches belonging to the defences of the late Roman fort extend further to the east than was previously assumed. For the first time, traces of a defensive wall built of tuff (stone) were found behind the ditches. This may have been preceded by a wall built of wood and earth. The coin evidence had pointed to a possible interruption of occupation in the middle of the 4th $\mathrm{c}$. and 
filling in of the ditches under Magnentius (350-353). ${ }^{36}$ The recent finds, however, and especially a gold coin of Constantius II dating to $360-361^{37}$ that was found in the oldest fill of the outer ditch, show that this break occurred later and that the building of the new fort dates to the second half of the 4th c. It can perhaps be correlated with the re-organization of the frontier defences under Valentinian I (364-375).

\section{Maastricht}

A new plan of the late Roman fortress at Maastricht has been published. ${ }^{38}$ In addition, it was possible to study the stratigraphy in the courtyard (Pandhof) to the church of Our Lady that extended from the time of Caesar until well into the Middle Ages. The importance of this place during the transition from the late Roman to the early mediaeval period is illustrated by a solidus of Valentinian III. Equally important are the many signs of industrial crafts: apparently combs of bone and probably roller-stamped terra sigillata wares were being made here.

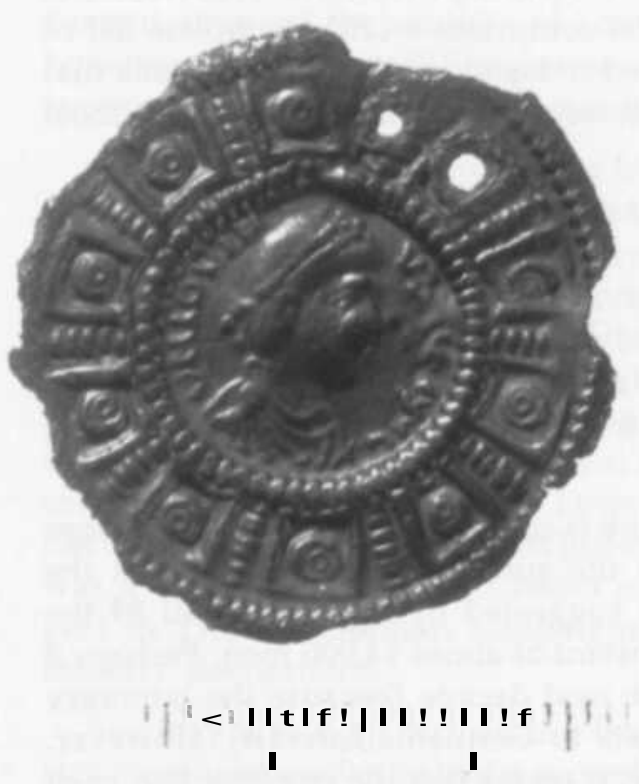

Fig. 11. Tin medallion of lovinus.

\section{A medallion of lovinus}

Mention must be made of a find from the 1980s that can contribute to a better understanding of the political circumstances on the Lower Rhine in the early 5th c. A tin medallion (fig. 11) with the portrait of lovinus (411-413) was found in 1981 by an amateur archaeologist on the bank of the Maas near Kessel-Lith (fig. 1) and was acquired a few years later by the Museum Kam. ${ }^{39}$ In 1976-77 the massive remains of masonry walls and blocks of sculptured stone had been discovered close to the place where the medallion was found, indicating that in late Roman times a large (probably military) facility was built here using spolia. At first sight the medallion resembles the gold adornments from Velp in which coins of Honorius and Galla Placidia of the years 405 and 425 are used. It differs from those, however, in the material (tin enriched with silver) ${ }^{40}$ the crude decoration on the rim, and the method of fabrication, for the centrepiece and border were cast as one; further, a genuine coin was not incorporated but a coin or medallion was used to make the mould in which the tin ornament was cast. The lettering from the rim of the original coin is hard to read but the reference to lovinus is certain: D(ominus) N(oster) IOVIN-VS P(ius)F(elix)AVG(ustus). With lovinus we find ourselves shortly after that disastrous night on New Year's eve 406 when the

36 Haalebos 1976, 204-5.

37 RIC VIII 225, no. 280. Find no. KE 1 4-4-291, found between excavation levels 4 and 5 in the lighter coloured fill of the outer southern ditch, at $31.67 \mathrm{~m}+$.

38 Panhuijsen 1996, map IV.

39 See De Nederlandse Rijksmusea 105 (1984) 234 and 237, fig. 2 on the right. The Museum Kam is now incorporated in the new Museum Het Valkhof at Nijmegen.

40 We are grateful to N. Roymans for his help in obtaining metal analyses of this object in the Science Laboratory of Philips in Waalre (X-ray spectrometry) and in the BR 1-reactor at Mol (Belgium) (Neutron Activation Analysis). The object is composed of 91-95\% tin ( $\mathrm{Sn}$ ) and 5.2-6.2\% silver (Ag). The silver content was slightly higher at the surface. Small quantities of the following elements were also present: chromium $(\mathrm{Cr})<.08 \%$, manganese $(\mathrm{Nn}) .043-.053 \%$, iron $(\mathrm{Fe})<5 \%$, cobalt $(\mathrm{Ca})<.01 \%$, nickel $(\mathrm{Ni})<.03 \%$, copper $(\mathrm{Cu}) .45-55 \%$, zinc $(\mathrm{Zn}) .03 \%$, arsenic (As) $.013-.018 \%$, antimony $(\mathrm{Sb}) .006-.007 \%$ and indium (In) $.008-.012 \%$. Percentages were calculated without taking into account the presence of possible other elements or oxides. 
German tribes had crossed the Rhine at Mainz. Iovinus came to power after two German princes acclaimed him emperor during the general confusion resulting from the struggle for power between Constantine III, the usurper in Britain, and the legitimate emperor Honorius. ${ }^{41}$ According to Olympiodorus, this event took place in a town called Mundiacum, in the province of Germania Secunda (the former province of Lower Germany, to which the modern-day Netherlands belongs). It is usually assumed that Mundiacum is a corruption of the name Mogontiacum (Mainz), but Mainz did not belong to Germania Superior but to Germania Prima. H. von Petrikovits has drawn attention to the fact that there are still many Roman settlements whose names are still unknown, and has indicated the possibility that the town should be placed somewhere north of the Moselle. The new find, as well as hoards with coins of Iovinus, ${ }^{42}$ shows that his activities were concentrated in Germania Secunda, and give rise to the supposition that his authority and influence were greatest there.

Catholic University of Nijmegen; University of Leiden

\section{APPENDIX: STAMPED TILES FROM COHORS XV VOLUNTARIORUM}

Type 1 (letters in relief)

COHXVvol: reversed in tabula ansata. The L is upside-down and is placed in the left ansa. Above the number xv is a line. Only one example of the stamp on a complete tegula ( 49 x 27 x $3.4 \mathrm{~cm}$ ) exists. See Bogaers 1977 , 628, fig. 4.

Type 2 (letters in relief)

COH.xv : The point has the form of a leaf or hedera. The drawing is constructed out of various fragments which do not belong to one another. Altogether there are 8 imprints from Woerden and one each from Bodegraven and Vleuten-De Meern. They all seem to have been used on tegulae, whose thicknesses range between 27 and $34 \mathrm{~mm}$. None of the upright edges of the tiles has survived. The contexts of the finds $\mathrm{m}$ Woerden allow a date in early Flavian times. See Bogaers 1977, 628, fig. 3 and also Beunder 1987, 67, fig. 41.

$\begin{array}{lll}1 \mathrm{COH}[. \mathrm{xV}] & \text { WRD. } 1980.372 . \mathrm{k} & 6[\mathrm{COH} .] \mathrm{XV} \\ 2 \mathrm{COH}[. \mathrm{XV}] & \text { WRD.1977.149.ks } & 7[\mathrm{COH} .] \mathrm{XV} \\ 3 \mathrm{CO}[\mathrm{H} . \mathrm{XV}] & \text { WRD.1976.101.k } & 8[\mathrm{COH} . \mathrm{xV} \\ 4 \mathrm{C}[\mathrm{OH} . \mathrm{XV}] & \text { WRD.1980.385.k } & 9[\mathrm{CO}] \mathrm{H} . \mathrm{XV} \\ 5[\mathrm{COH} .] \mathrm{XV} & \text { WRD.1977.149.kp } & 10 \mathrm{COH} . \mathrm{XV}\end{array}$

WRD.1975.56.k

WRD.1975.2.ka

Private collection

Vleuten-De Meern

$5[\mathrm{COH}.] \times \mathrm{WV}$ WRD.1977.149.kp

Private collection: Bodegraven

Type 3 (indented letters)

COHXV : Remarkably heavy letters with very clear seriffes. The stamp is known from 7 examples from Woerden and single fragments from Alphen-Zwammerdam and Valkenburg. The type is known in LeidenRoomburg. The stamps are found in Woerden on fragments of tegulae with a thickness between 26 and $34 \mathrm{~mm}$ and also on a $62 \mathrm{~mm}$ thick later (no. 2). The presence of upright edges is attested on two fragments of tegulae. The contexts of the finds in Woerden show mat this stamp could only have been used since late Flavian times.

$1 \mathrm{COHXV}$
$2 \mathrm{COHXV}$
$3 \mathrm{COHXV}$
$4 \mathrm{COH}[\mathrm{XV}]$
$5 \mathrm{COH}[\mathrm{XV}]$
6 [COH]XV
7 [CO]HXV
$8 \mathrm{COH}[\mathrm{XV}]$
$9 \mathrm{COHXV}$
$10 \mathrm{C}[\mathrm{OHXV}]$

WRD.1978.281.k

WRD.1978.208. k

WRD.1977.149.kc

Private collection

WRD.1978.266.k

RMO 1887: Woerden

WRD.1977.149.kf

Private collection: Zwammerdam

Bogaers 1977, 627, Abb. 2 a: Holland?

Valkenburg 1986, find no. 41-4-445

\section{Type 4 (indented letters)}

COHXV : The stamp is similar to type 3 but is somewhat smaller. The letters are much straighter and angular. The stamp was found on a square later (no. 1: $31 \times 29.6$ × $3.5 \mathrm{~cm}$ ) and on a unusual rectangular tile with lines pre-scratched into the surface (no. $2:>22 \times 12.5 \times 6 \mathrm{~cm}$ ). The latter could apparently be broken into triangular pieces along the marked-out lines: a larger one, with a base measuring $29.6 \mathrm{~cm}$, and two smaller ones whose maximum length was $19 \mathrm{~cm}$. A further stamp from Woerden was found on a small fragment which because of its thickness (more than $45 \mathrm{~mm}$ ) probably aid not belong to a tegula. This type, hitherto unpublished, is also known from Leiden-Roomburg.

41 RE IX.2 (1916) 2012-13; De Boone 1954, 124; Von Petrikovits 1980, 275-76 and 288.

42 Werner 1958, 400-1. For the coins of lovinus see Cohen 1880-92, 201-2. 
$1 \mathrm{COHXV}$
$2 \mathrm{COHXV}$
3 [co]Hxv
WRD.1978.291.kc

WRD. 1977.124.k

WRD.1977.149.kd

\section{Type 5 (indented letters)}

COH.XV : This stamp, which due to the form of the letters is very similar to types 3 and 4 , is conspicuous in lacking a frame. The only known imprint comes from Woerden and is on a triangular piece of tile which must have been broken from a larger slab (see Type 4,2). The maximum preserved length is $29.6 \mathrm{~cm}$.

$1 \mathrm{COH} . \mathrm{xv}$

WRD.1977.120.k

\section{REFERENCES}

Alföldy, G. 1968 Die Hilfstruppender römischen Provinz Germania Inferior(Epigraphische Studien 6).

Baatz, D. 1973 "Einige Funde obergermanischer Militär-Ziegelstempel in der Germania inferior," in W. A. van Es et al. (edd.), Archeologie en Historie Opgedragen aan H Brunsting bijzijn zevenstige verjaardag (Bussum) 219-24.

Bechert, T. and W. J. H. Willems 1995 Die romische Reichsgrenze von der Mosel bis zur Nordseeküste(Stuttgart)

Beunder, P. C. 1987 Castella en Havens, Kapellen en Hoven, van Albaniana tot Laurum, viraBode(lo)graveen Zwadenburg(Bodegraven) Bogaers, J. E. 1977 "Auxiliaria," in J.. Fitz (ed.), Limes. Akten des XI.Int Limeskongresses (Budapest) 601-32.

Bogaers, J. E. 1978 "Wat staat er op het vat van Velsen?", Westerheem 27, 8-12.

Bogaers, J. E. 1994 "Sol Elagabalus und die cohors III Breucorum in Woerden (Germania inferior)," OudMedLeiden74, 153-59.

Boone, W. J. de, 1954 De Franken van hun eerste optreden tot de dood van Childerik (Amsterdam)

Bowman, A. K. and J. D. Thomas, The Vindolandawriting-tablets, Tabulae Vindolandenses11 (London)

Cohen, H. 1880-92 Description des monnaies frappéessous l'empire romain 8 (Paris; repr. Leipzig 1930).

Dobson, B. 1978 Die Primipilares Entwicklung und Bedeutung, Lauflahnen und Persönlichkeiten eines römischen Offiziersranges (BJb Beiheft 37)

Eck, W. and E. Paunov 1977 "Ein neues Militärdiplom für diè Auxiliartruppen von Germania Inferior aus dem Jahr 127," Chiron 27, 335-53.

Enckevort, H. van and J. R. A. M. Thijssen 1996 Graven met beleid. Gemeentelijkarcheologisch onderzoek in Nijmegen 1989-1995 (Nijmegen)

Enckevort, H. van, and K. Zee 1996a Het Kops Plateau Prehistorische grafheuvels en een Romeinse legerplaats in Nijmegen (Abcoude/Amersfoort)

Enckevort, H. van, and K. Zee 1996b "Bataven op het Kops Plateau m Nijmegen," Scarabée 25 (Dec. 1996) 20-22.

Goguey, R. and M.. Reddé 1995 Le camp légionnaire de Mirebeau (RGZM Monog. 36)

Graafstal, E P. 1998 "Vleuten-De Meern, Veldhuizen," in D. H. Kok, J. P. ter Brugge, S. G. van Dockum and F. Volgelzang (edd.), Archeologische kroniekprovincie Utrecht 1996-1997(Utrecht) 137-68.

Haalebos, J. K. 1976 "Munten uit Maurik," OudMedLeiden 57 (1976) 197-226.

Haalebos, J..K. 1977: Zwammerdam-NigrumPullum Ein Auxiliarkastell am Niedergermanischen Limes (Cingvla III, Amsterdam)

Haalebos, J. K. et ai 1995 "Castra und Canabae," Libelli Noviomagenses 3 (Nijmegen)

Haalebos, J. K. 1996 "Ein römisches Getreideschiff 'm Woerden," JbRGZM43, 475-509.

Haalebos, J. K. and W. J. H Willems, in press, "Der Niedergermanische Limes in den Niederlanden, 1995-1997," Akten des XVIIInt . Limeskongresses in Zalău (Romania 1997\} forthcoming

Hallewas, D. P. and R. M. van Dierendonck 1993 "The Valkenburg-Marktveld and Valkenburg-the Woerd excavations, 19851988: a preliminary report," in D. P. Hallewas, R. M..van Dierendonck and K. E. Waugh (edd.), The Valkenburg Excavations 1985-1988 (Nederlandse Oudheden 15, Amersfoort) 11-46.

Hessing, W. J. H. 1999 "Building programmes for the Lower Rhine Limes. The impact of the visits of Trajan and Hadrian to the Lower Rhine," in:H. Sarfati) et al. (edd.), In discussion with thepast (Zwolle/Amersfoort) 149-56.

Hessing, W, M. Polak, W. Vos and S. Wynia 1997 Romeinen langs de snelweg, Bouwstenen voor Vechtens verleden (Abcoude/Amersfoort)

Oldenstein-Pferdehirt, B. 1984 "Die Geschichte der Legio VIII Augusta," JbRGZM31, 397-433.

Panhuijsen, T. S. A. M. 1996 Romeins Maastricht en zijn beelden (Maastricht/Assen)

Petrikovits, H. von, 1980 Die Rheinlande in romischer Zeit (Dusseldorf)

Rüger, C. B. 1972 "Gallisch-Germanischen Kurien," EpStud 9, 251-60.

Weerd, M. D. de, 1977 "The date of Valkenburg 1 reconsidered: the reduction of a multiple choice question," in B., L.van Beek et al (edd.), Ex horreo (Cingvla IV, Amsterdam) 255-89.

Werner, J. 1958 "Kriegergräber aus der ersten Hälfte des 5. Jahrhunderts zwischen Scheide und Weser," B/b 158, 372-413.

Wynia, S. L. 1999 "Caius was here. The emperor Caius' preparations for the invasion of Britannia: new epigraphic evidence," $\mathrm{m} \mathrm{H}$. Sarfatijet al. (edd.), In discussion with the past (Zwolle/Amersfoort) 145-47. 